December 2014

\title{
Website Blocked: Filtering Technology in Schools and School Libraries
}

Jennifer M. Overaa

San Jose State University, joveraa@comcast.net

Follow this and additional works at: https://scholarworks.sjsu.edu/ischoolsrj

Part of the Communication Technology and New Media Commons, Curriculum and Instruction Commons, Education Law Commons, Education Policy Commons, Elementary and Middle and Secondary Education Administration Commons, Elementary Education and Teaching Commons, First Amendment Commons, Information Literacy Commons, Junior High, Intermediate, Middle School Education and Teaching Commons, and the Scholarly Publishing Commons

\section{Recommended Citation}

Overaa, J. M. (2014). Website Blocked: Filtering Technology in Schools and School Libraries. School of Information Student Research Journal, 4(2). https://doi.org/10.31979/2575-2499.040204 Retrieved from https://scholarworks.sjsu.edu/ischoolsrj/vol4/iss2/4

This article is brought to you by the open access Journals at SJSU ScholarWorks. It has been accepted for inclusion in School of Information Student Research Journal by an authorized administrator of SJSU ScholarWorks. For more information, please contact scholarworks@sjsu.edu. 


\title{
Website Blocked: Filtering Technology in Schools and School Libraries
}

\begin{abstract}
This paper investigates the impact of filtering software in $\mathrm{K}-12$ schools and school libraries. The Children's Internet Protection Act, or CIPA, requires that public schools and school libraries use filtering technology in order to receive discounted rates on technology. As a result, nearly all public elementary and secondary schools today use filtering technology. While the provisions of CIPA narrowly define the content to be blocked, filters are often set to block much more than is required. Filtering technology is often ineffective, and many unobjectionable sites end up being blocked, including Web 2.0 sites and tools needed to educate students in a 21 st century learning environment. Filtering software raises other issues as well, such as First Amendment implications, a possible "digital divide" between students that have unfiltered access to online content at home and those that do not, and the loss of opportunity to educate students on how to be good digital citizens. These issues should be acknowledged and addressed. There are many options available to librarians, educators, administrators, and other stakeholders that can increase students' access to online information and educational tools while still protecting children from inappropriate online content and complying with the requirements of CIPA.
\end{abstract}

\section{Keywords}

filtering software, filtering technology, CIPA, Children's Internet Protection Act, internet safety, technology in schools

\author{
About Author \\ Jennifer Overaa graduated with honors from Oregon State University, receiving a BS in Business \\ Administration. She also holds a JD from University of California, Hastings College of the Law and has \\ been a member of the California State Bar since 1993. She practiced law for more than a decade in the \\ fields of construction litigation, business litigation, and high tech transactional work. Ms. Overaa is a \\ current MLIS candidate at San Jose State University with an interest in public, academic, and legal \\ librarianship.
}


Internet access at schools has exploded over the last 15 years, and today nearly $100 \%$ of primary and secondary students have access to the Internet at school. In addition, the way technology is being used is changing rapidly, with a move away from static first generation websites and the advent of more collaborative and content building sites, blogs, wikis, and social media. As student Internet use increases and changes, schools are faced with a variety of technical, legal, educational, and philosophical challenges. The Children's Internet Protection Act (CIPA), a federal law passed in 2001, requires public schools and libraries to use filters as a condition of receiving federal funding for technology. Therefore, to protect children from inappropriate content, and to comply with the Children's Internet Protection Act (CIPA), almost all K-12 schools use filtering software to block undesirable content.

Is filtering software the best or only way to protect our students? Research shows that filtering software is not $100 \%$ effective in protecting students from inappropriate content, and in fact often blocks sites that do not contain offensive content. The continued use of filtering software also has First Amendment implications. Students are blocked from information they may want or need to access and even if the site can be unblocked by request, that extra step creates a chilling effect on free speech. The use of filtering software negatively impacts the quality of education by blocking Web 2.0 sites and online tools students need in order to receive a $21^{\text {st }}$ century education. Filtering software may have its place in schools; however, careful and limited use of the software combined with non-technological strategies will better enable students to access the information and tools they need for $21^{\text {st }}$ century learning while remaining protected from inappropriate content.

\section{Literature Review}

Recent research on this topic includes two articles published in 2010. Willard (2010) explores the notion that by relying on filters to protect our children, we are creating a false security that information retrieved is not only safe but also credible, and blocked information is neither safe nor credible. In fact, research and testing on filtering software shows that this is often not the case, and we are doing the students a disservice by depriving them of the opportunity to learn how to navigate safely online and assess the quality of the information retrieved (Willard, 2010). Jansen (2010) explores the issue from an intellectual freedom perspective, noting the rise of Web 2.0 sites and arguing that blocking social media sites in schools calls into question the "erosion of the principles of intellectual freedom for youth" (p. 48). Jansen also discusses the negative impact that filters have had on $21^{\text {st }}$ century learning. School librarians and teachers consistently report that their schools' filters deny access to Web 2.0 tools such as 
wikis, blogs, and collaborative sites and tools (Jansen, 2010). Both articles make recommendations to permit greater student online access while still protecting and educating the students.

A number of informative studies regarding the use of technology at school and home have been published since these articles were written. The Bill \& Melinda Gates Foundation (2010), the National Cyber Security Alliance (2011), the American Association of School Librarians (2012), the U.S. Department of Education (2010 and 2012), and the Pew Research Center (2013) have all released studies and statistics regarding student Internet use and access at school and home, the impact of the Internet on education, and/or efforts at cyber-education. Cumulatively, these studies highlight the increasing importance of technology and Internet access to modern-day education. Technology is prevalent at schools, and teachers desire to continue using technology in their classrooms. One survey of middle school and high school teachers found that $92 \%$ of these teachers believe that the Internet "has a 'major' impact on their ability to access content, resources, and materials for their teaching" (Purcell, Heaps, Buchanan, \& Friedrich, 2013, p. 2). Another study of 40,000 public school classroom teachers found that an astounding $95 \%$ either somewhat or strongly agree that digital resources (such as classroom technology and Web-based programs) engage students in learning, and 93\% agree that these resources help student academic achievement (Bill \& Melinda Gates Foundation, 2010). This wide spread approval of technology as a teaching tool will continue to gain strength as new teachers favor technology to an even greater degree than their veteran counterparts (Bill \& Melinda Gates Foundation, 2010).

However, research also shows that filtering of online content is "nearly universal across schools or school libraries" (American Association of School Librarians [AASL], 2012, p. 13) and can negatively impact the way technology is used in schools. In one survey, teachers report that filters impede student research (52\%), discount social aspects of learning (42\%), and impede continued collaboration outside of face-to-face opportunities (25\%) (AASL, 2012).

\section{Discussion}

There are many challenges to having Internet access in schools and school libraries. As primary and secondary schools across the country develop $21^{\text {st }}$ century learning environments with increased and better technology in school libraries and classrooms, librarians, school staff, and districts struggle with how to manage the online environment in a way that protects the children from inappropriate content, complies with applicable laws, and still supports learning.

To meet that challenge, almost all public K-12 schools use filtering software. In Willard's 2010 article, she cites a National Cyber Security Alliance 
report that asked "Which of the following describes the policies and/or procedures your school/school district uses to ensure appropriate use of technology and the Internet?" According to Willard, "of the school administrators surveyed, 95 percent identified filters, and 91 percent identified the blocking of social media networking sites as the means to ensure appropriate in-school Internet use" (p. 56). Jaeger and Zan find an even higher use of filters in schools. In their 2009 article, they state that "[a]ccording to the latest report by the Department of Education ... by 2005, 100 percent of public schools had implemented both the Internet filtering strategy and safety policy strategy" ("How many public schools", para. 1). A recent study conducted by the American Association of School Librarians found that "[w]hen asked whether their schools or districts filter online content, $98 \%$ of the respondents said content is filtered" (AASL, 2012, Executive Summary, p. 1) and when respondents were asked if content for students is filtered by their school or the district, $100 \%$ of the respondents answered "Yes" (AASL, 2012, Executive Summary, p. 2). Whatever the exact figure, it is clear that nearly all schools rely on filtering technology.

\section{The Children's Internet Protection Act}

Why is filtering so prevalent? The Children's Internet Protection Act, or CIPA, is a federal law that makes filtering essentially mandatory for public schools. It requires a school to show that it is using filtering technology to block obscene images, child pornography, or images that are "harmful to minors" before it can receive significantly discounted rates from the federal government (known as ERates) on technology services and equipment. Without this discount, public schools are not able to afford the technology.

Legal background of CIPA. CIPA is the culmination of several failed attempts by the federal government to regulate content and protect children from undesirable content on the "virtually unregulated Internet" (Menuey, 2009, p. 41). Prior to CIPA, the Communications Decency Act of 1996 made it unlawful to place adult-oriented material online where minors could access it; however, in the case of Reno v. ACLU (1997), the Supreme Court ruled that this act was unconstitutional (Menuey, 2009). Congress tried again to restrict online content by implementing the Child Online Protection Act of 1998 ("COPA"), which "prohibited any transmission for commercial purposes of material deemed "harmful to minors" (Menuey, 2009, p. 41) as defined by "contemporary community standards" (Menuey, 2009, p. 41). Although the Supreme Court in Ashcroft v. ACLU found the community standard test appropriate, it sent the case back down to the lower court for further review and barred the federal government from enforcing the law until review was complete (Menuey, 2009). 
The lower court eventually issued a permanent injunction against COPA's enforcement, finding it unconstitutionally vague and overbroad (ACLU $v$. Gonzales, 2007).

While COPA was still mired in legal limbo, Congress quickly passed yet another Internet regulation act - the Child Pornography Prevention Act of 1996 ("CPPA"), "which sought to bar from the Internet sexually explicit material involving what 'appear(s) to be a minor,' including 'virtual child pornography' and 'morphed' child pornography" (Menuey, 2009, p. 41). Again, Congress failed - in Ashcroft v. Free Speech Coalition (2002) the Supreme Court struck down CPPA for being overly broad and therefore unconstitutional.

Learning from its mistakes, Congress finally found limited success in controlling online content with the Children's Internet Protection Act ("CIPA"), signed into law in late 2000. This act differed from its failed predecessors by focusing on the controlling the recipient - public schools and libraries - rather than the distributor of questionable content (Menuey, 2009). "Instead of placing restrictions on the Web, CIPA places restrictions on schools and libraries that receive federal funding" (Meuney, 2009, p. 41). In addition, for the first time, CIPA used Congress' power under the spending clause of the U.S. Constitution to regulate content (Jaeger \& Yan, 2009). "CIPA's force comes from [this power]; that is, Congress can legally attach requirements to funds that it gives out" (Jaeger \& Yan, 2009, "Why were only libraries and schools chosen", para. 4).

In United States v. ALA (2003), the ALA challenged CIPA's constitutionality. The Supreme Court reversed a lower court's finding that mandatory filtering for public libraries was unconstitutional. Justice Rehnquist, in writing for the majority, found that:

[A]ssuming again that $\square$ public libraries have First Amendment rights-CIPA does not "penalize" libraries that choose not to install such software, or deny them the right to provide their patrons with unfiltered Internet access. Rather, CIPA simply reflects Congress' decision not to subsidize their doing so. To the extent that libraries wish to offer unfiltered access, they are free to do so without federal assistance. (U.S. v. ALA, 2003, p. 212)

Although this case focused on public libraries, the decision in effect precludes public schools from making a similar argument. For now, CIPA is the law.

CIPA's implementation. What does CIPA require of public schools and libraries? Simply put, in order to receive a Universal Service Discount for technology ("E-rate"), public schools and libraries must have an Internet Safety Policy that includes a "technology protection measure" 
that filters or blocks visual images that are (1) obscene; (2) child pornography; or (3) "harmful to minors", generally defined as "depictions of nudity and sexual activity that lack artistic, literary, or scientific value" (CIPA, 2001; Jaeger \& Yan, 2009, "The legal road to CIPA," para. 1).

CIPA also requires that the Internet Safety policy "address" (1) access by minors to "inappropriate matter" online (as determined by a local agency, such as the school district); (2) the safety and security of minors while using e-mail, chat, or other means of direct communication; (3) unlawful activity; and (4) unauthorized disclosure of personally identifiable information about minors. It is important to note that CIPA does not specifically require filtering technology be used as the solution to address these additional concerns. CIPA merely specifies that these issues be "addressed" in an Internet Safety Policy. Filtering technology is only required to block obscenity, child pornography, and images that are "harmful to minors" as defined by the act.

\section{Impact of Filtering Software in Schools}

Because of CIPA, filtering is a reality in almost all K-12 public school libraries and classrooms. The purpose of and the benefit to using filtering software is that it can help protect children from accessing adult content at school. Properly implemented, it will filter out a good deal of inappropriate content that students may otherwise knowingly or accidentally access. Pre-CIPA studies found that $60 \%$ of all Web-site visits were sexual in nature, and that $53 \%$ of teens had viewed websites that included pornography or violence. Of those teens, $91 \%$ came upon those inappropriate websites unintentionally (Byrd, V., Felker, J., \& Duncan, A., 2001). Schools are an important point of access to online content for teens, and thus can be instrumental in protecting teens and children from pornography and violence. "[F]or a growing portion of the online teen population, schools have become an important venue for internet use for a significant number of teens ... More than three in five online teens who use the internet from multiple locations list school as the location where they go online most often" (Lazarinis, 2010, p. 158). As a significant online access point for students, schools have an important role to play in protecting students from accidentally stumbling upon inappropriate content, and filters are one key tool that can assist with this task.

While the benefits of filtering seem clear, there are detrimental effects to filters as well. Many scholars and free speech proponents, including the American Library Association, argue that the use of filtering technology in schools and libraries raises significant concerns. The improper use of filtering technology may infringe on student's First Amendment rights, impede a $21^{\text {st }}$ century education, result in a lost opportunity for students to be educated in online 
citizenship, create a digital divide, and block sites deemed improper by the designers of the software, rather than educators.

The evolution of technology in schools. In analyzing the impact of filters, it is very important to highlight that the landscape has changed significantly since the drive to pass legislation to protect children from online content began. Congress' efforts to legislate online content for children began with CDA in the mid 1990s, and culminated with CIPA, passed in 2001. In 1995, when these efforts began, just $8 \%$ of public schools (both elementary and secondary combined) had computers with Internet access for either instructional or administrative purposes (Digest of Education Statistics, 2012, Table 108). By 2000 that number had climbed to $77 \%$, and by 2008 , the percentage stood at $98 \%$ (Digest of Education Statistics, 2012, Table 108).

In addition, the ratio of students to computers has dropped by more than half since 2000 (Digest of Education Statistics, 2012, Table 108), which suggests that students may have access to computers more frequently. According to a recent study, $59 \%$ of teachers reported that their students use computers at least twice per week in school (National Cyber Security Alliance [NCSA], 2011), and $81 \%$ said such use occurs at least once a week (NCSA, 2011). The usage remained consistent against all age groups, from kindergarten to high school (NCSA, 2011). Furthermore, 89\% said their schools have a dedicated computer lab for student use (NCSA, 2011). It is almost certain that not only Internet access, but Internet usage, has increased significantly at schools over the last decade.

The way technology is used at schools has changed as well, with more technology integrated directly into the classroom. In 2009, 97\% of American public school teachers had computers in their classroom, with Internet access available for $93 \%$ of those computers. The ratio of students to computers in the classroom was 5.3 to 1 (U.S. Department of Education, 2010, Teachers' Use). Teachers reported that they or their students used computers in the classroom during instructional time often $(40 \%)$ or sometimes (29\%) (U.S. Department of Education, 2010, Teachers' Use).

That percentage will continue to increase. Teachers want technology in their classrooms. As of $2010,81 \%$ of teachers say that "up-to-date informationbased technology that is well integrated into the classroom is absolutely essential $(38 \%)$ or very important $(43 \%)$ in impacting student achievement" (Bill \& Melinda Gates Foundation, 2010). A full $95 \%$ of teachers agree that technology engages students in learning (Bill \& Melinda Gates Foundation, 2010). The U.S. federal government also promotes and supports "learning powered by technology" (National Education Technology Plan, 2010, p. 1). The National Education Technology Plan 2010 "calls for applying the advanced technologies 
used in our daily personal and professional lives to our entire education system to improve student learning, accelerate and scale up the adoption of effective practices, and use data and information for continuous improvement" (p. 1). The plan envisions, among other things, broadband and wireless coverage to support all campuses nationwide, access devices for every student and educator, and access to open and free electronic educational resources such as digital textbooks, digital libraries, tutoring systems, podcasts, games, and similar educational content.

In Watters' (2012) blog, she puts the evolution of technology at schools into perspective, noting that while technology has changed significantly, CIPA has not:

CIPA was signed in to law in 2001. That's worth highlighting, I think, when we talk about "children's Internet protection" as the Internet and computing were very different a decade ago. For a little perspective: 2001 was the year before Maine's historic one-to-one laptop initiative was underway. It was a year before a young Mark Zuckerberg entered Harvard. It was three years after Sergei Brin and Larry Page founded Google, but three years before the company went public. It was three years before Tim O'Reilly coined the term "Web 2.0." Apple introduced the first iPod in 2001; but it was six more years before the iPhone and nine before the iPad hit the market. Technology and society have changed substantially in the intervening years; CIPA has not. (Watters, 2012)

The National Education Technology Plan 2010 also acknowledges a tension between student safety and connectivity. In a sidebar, it notes that filters required by CIPA not only block access to legitimate learning content and tools, but also that CIPA requirements create a significant technical challenge to accessing school networks through students' personal devices such as cell phones and laptops (National Education Technology Plan, 2010).

First Amendment implications. Filtering software undeniably has First Amendment implications. CIPA only requires that filters block visual depictions of child pornography, obscenity, and material harmful to children - but no existing filter can be that precise. Any filter used in a school "will both overblock and under-block" (Chmara, 2010, p. 19); in other words, some inappropriate material will slip through the filter and a significant amount of nonoffensive and appropriate content will unintentionally be blocked. Technology 
does not exist that can selectively and successfully block out inappropriate materials without also blocking out valuable information (Heins, Cho and Felman, 2006; Meeder, 2005). At the time CIPA was enacted, a report conducted by the Free Expression Policy Project summarized the results of more than 70 studies on the performance of Internet filters. The report revealed substantial over blocking by a wide variety of software filters (Heins, et al., 2006). ${ }^{1}$ A subsequent review conducted in 2006 found that "despite improved technology and effectiveness in blocking some pornographic content, filters are still seriously flawed" (Heins, et al., 2006, p. ii). Recent surveys confirm that filters continue to impact students' ability to access the information they seek. According to an October 2, 2012 press release released by the American Library Association (ALA) regarding its survey results on filtering in schools, "student learning is impeded by school and/or district filters ... Fifty-two percent indicated that school filters interfere with student's research when completing keyword searches" (ALA, 2012, para. 4). Student access to appropriate content is most certainly blocked by the use of software filters.

In most cases, sites can be unblocked - however, it isn't easy. In a recent study by the American Association of School Librarians (AASL), 92\% of respondents indicated they could request that a site be unblocked, but " $68 \%$ of the decisions to unblock a site are made at the District level and only $17 \%$ of the decisions are made at the building level" (AASL, 2012, Executive Summary, p. 3 ). It can also take some time to get a site unblocked. Only $27 \%$ can have the site unblocked within a few hours - most have to wait much longer (AASL, 2012, Supplemental Report). One in five say it takes more than a week to unblock a site (AASL, 2012, Supplemental Report). In addition, even when a site can be unblocked, the extra step may violate First Amendment rights and certainly interferes with immediate and free access to information. A student may be unwilling to take the extra step to request that a site be unblocked, especially if the subject material is of a more sensitive or personal nature - for example, a homosexual student researching information about his or her sexual orientation. "[T]o request access to [an erroneously blocked site] chills the dissemination of ... speech and is therefore a violation of the First Amendment" (Byrd, Felker and Duncan, 2001, p. 9).

Impact on $21^{\text {st }}$ century learning. Filtering technology does much more than block images of pornography, obscenity, or images harmful to children as

\footnotetext{
${ }^{1}$ For example, several filters blocked House Majority Leader Richard "Dick" Arney's website upon detecting the word "Dick"; another filter blocked the Declaration of Independence, Shakespeare's complete plays, Moby Dick, and Marijuana: Facts for Teens (published by the National Institute on Drug Abuse); and a third filter blocked a search for "The Owl and the Pussy Cat" upon detecting the word "pussy".
} 
required by CIPA. A 2010 review of thirty public schools found that "most [schools] set its filter to block more than required by CIPA" (Jansen, 2010, p. 51). What, exactly, are the filters blocking, and why is it important?

Filters in schools are set to block many Web $2.0^{2}$ sites. Social media sites, IM/online chatting sites, gaming sites, and video services such as YouTube and SchoolTube are filtered at most schools (AASL, 2012, Supplemental Report). As of 2008, according to a survey of more than 600 participants, $59 \%$ responded that their students are not allowed to view or participate in blogs, $50 \%$ are denied access to social bookmarking, and another 68\% are blocked from some search engines (Bell's article [as cited in Jansen, 2010]). One high school librarian/technology coordinator complains that her district filters "forums" which seem to include "anything with a 'comment' button. That means all blogs, most Web 2.0 sites, and many run of the mill sites that allow users to add comments..." (Willard, 2010, p. 56).

Why should we care? Well, to maintain a competitive edge in the world market, students must develop $21^{\text {st }}$ century skills by becoming experts in collaboration, critical thinking, complex problem solving, and multimedia communication (Jansen, 2010; U.S. Department of Education, 2010). The importance of interactive online tools to $21^{\text {st }}$ century dominates educational discourse (Jansen, 2010). In order to become productive members of a globally competitive workforce, students need access to the technology that professionals routinely use, such as wikis, blogs, and digital content for research, communication, and collaboration; inquiry and visualization tools for gathering and analyzing data; and graphical and 3D modeling tools for design (Jansen, 2010).

Students are already using Web 2.0 sites as educational tools at home. For example, a full ninety-six percent of 9- to 17-year-old students participate in online social networks and of that group, 59\% use social media to talk about educational topics and 50\% talk specifically about schoolwork (Ramaswami, 2010). Many social media sites provide access to information not accessible by searching traditional sources. Historical videos on YouTube, podcasts of radio transcripts on iTunes, current topics found only on Wikipedia and not in other encyclopedias, and blogs maintained by authors, journalists, governments, nonprofits, and scientific organizations are all accessible only through Web 2.0 sites (Jansen, 2010).

2 The term "Web 2.0" was coined in 2004 and is defined as "a web of multi-sensory communication"; "a matrix of dialogues, not a collection of monologues"; and a "user-centered web" (Maness, 2006, Introduction, para. 1). In other words, Web 2.0 indicates a more interactive, dynamic, and personalized experience where the line between creation and consumption of content is blurred (Maness, 2006, Introduction, para. 1). 
National and international educational standards recognize the importance of and promote the use of Web 2.0 tools. The International Society for Technology in Education (ISTE), an international premier membership association for educators, asks teachers to design and develop digital age learning experiences and assessments; model and facilitate use of current and emerging digital tools; teach safe use of digital information and technology; model digital etiquette and responsible social interactions related to the use of technology and information, and participate in global learning communities using digital age communication and collaboration tools (ISTE, 2012). The U.S. Department of Education has developed a "National Education Technology Plan" that calls for "applying the advanced technologies used in our daily personal and professional lives to our entire education system" (U.S. Department of Education, 2010, Introduction) by "leveraging [technology] to provide engaging and powerful learning experiences and content" (U.S. Department of Education, 2010, Executive summary). The plan envisions students using real-world tools such as "wikis, blogs, and digital content for the research, collaboration, and communication....that allow them to grapple with real-world problems" (U.S. Department of Education, 2010, Executive summary).

However, "[d]espite this recognition of the importance of teaching students to use $21^{\text {st }}$-century tools appropriately, school librarians and teachers increasingly report that their schools' Internet filters deny access to these valuable resources" (Jansen, 2010, p. 48). In 2012, "librarians ... reported that filtering discounts the social aspect of learning (42 percent) and filtering hampers continued collaboration outside of face-to-face opportunities (25 percent)" (American Library Association, 2012, press release). The U.S. Department of Education is also concerned, noting in its 2010 National Educational Technology Plan that "ensuring student safety on the Internet is a critical concern, but many filters designed to protect students also block access to legitimate learning content and such tools as blogs, wikis, and social networks that have the potential to support student learning and engagement" (U.S. Department of Education, 2010, "Infrastructure: Access and Enable" section). Web 2.0 sites and tools are crucial for today's educational environment, but filters often deny students and teachers access to these resources.

Lost opportunity for online education. Relying on filters may deprive public school librarians and teachers the opportunity to teach students how to be savvy searchers or how to evaluate the accuracy of information. (Adams, 2010). Adams notes that schools have a responsibility to educate children on how to navigate the Web. She states: 
[S]chools 'grow' citizens who must develop skills to evaluate information from all types of sources in multiple formats, including the Web. Relying solely on filters does not teach young citizens how to be savvy searchers or how to evaluate the accuracy of information ... [F]ilters protect minors only when they are using the Web in schools and libraries, not during their Web use at home, in the homes of friends, or on their personal web-enabled cell phones. (Adams, 2010, p. 11)

High levels of filtering make the Internet unusable, and students will go elsewhere to gain online access. In that space, they will more likely be unsupervised and not taught how to navigate the Internet critically, appropriately, and safely. In her 2010 article, Willard likens educating students about online behavior to teaching children to swim. "Without robust access to these technologies in school, trying to prepare students for their future as effective users of online information is like trying to teach children to swim without a swimming pool" (Willard, 2010, p. 53).

Of greater concern is that even when there is an attempt to educate students regarding online behavior, there is currently a notable disconnect among teachers, administrators, and IT specialists regarding both cyber-education requirements and the success of cyber-education programs. In a survey conducted by the National Cyber Security Alliance (NCSA) in 2011, only 33\% of teachers believe their district requires cyber-safety curriculum, while $68 \%$ of administrators and $64 \%$ of IT specialists believe so (NCSA, 2011). Furthermore, $81 \%$ of both administrators and IT specialists believe their districts are doing an adequate job of preparing students in cyber-security, cyber-safety and cyberethics, while only $51 \%$ of teachers believe so (NCSA, 2011). According to the same study, it appears that teachers receive little to no actual training; the study shows that most teachers $(86 \%)$ received fewer than 6 hours of cyber-security, cyber-safety and cyber-ethics training in the prior year, with $36 \%$ receiving no training whatsoever (NCSA, 2011). However, given the opportunity, most would like to learn. Seventy-six percent of teachers are interested in receiving training in these areas (NCSA, 2011). If students are to be educated in these areas, there will need to be increased communication between administration, teachers, and IT specialists in order for effective education to happen.

Digital divide. Depending solely on filters for content management may also create an unequal educational experience, or digital divide, based on income. Students from lower income households may not have online access at home and have to rely mostly or solely on school computers (where content is filtered). 
While the digital divide was of greater concern even five years ago, as access to technology increases, the divide has lessened. In 2008, of teens living in households earning less than $\$ 30,000$ per year, 56\% went online most often from home and 26\% did so from school (Arafeh, Lenhart, McGill, Rankin and Smith, 2008). In comparison, in $2008,87 \%$ of teens living in households earning more than $\$ 75,000$ per year went online most often from home, and just $11 \%$ from school (Arafeh, et al., 2008). However, since 2008, teens appear to have increasingly greater access to online technology even at lower income levels, particularly through cell phones. One 2013 study found that 9 in 10 teens have access to a computer at home and about 3 in 4 teens say they access the Internet on cell phones, tablets, or other mobile devices at least occasionally. (Cortesi, Duggan, Gasser, Lenhart, and Madden, 2013). Although teens that live in lowerincome and lower-education households are somewhat less likely to use the Internet in any capacity, for those that do, they are just as likely and in some cases more likely to use cell phones as a primary point of access to the Internet (Cortesi, et al., 2013).

Despite this increasing access to technology at home across all socioeconomic levels, the digital divide appears to still exist between lower income and higher income students at the same school and across school districts. Increased home access to the Internet through cell phones or shared computers does not necessarily mean easy access to the digital technologies used by educators at school. A recent teacher survey highlights disparities in access to digital tools; more than half $(54 \%)$ of the respondents say all or almost all of their students have sufficient access to digital tools while in school, but just $18 \%$ say the same is true at home (Buchanan, J., Friedrich, L., Heaps, A. \& Purcell, K., 2013). In addition, " $[\mathrm{t}]$ eachers of the lowest income students are the least likely to say their students have sufficient access to the digital tools they need, both in school and at home" (Buchanan, J., et al., 2013, p. 3). Although the digital divide still exists, it is narrowing as technology becomes cheaper and more prolific. However, students continue to be impacted by their inability to access needed digital tools outside of the school setting.

Filter set by software company rather than educators. A final issue raised by filtering software is that a software designer rather than an educator creates the filter. "[B]ecause filtering software companies make the decisions about how the products work, content and collection decisions for electronic resources in schools and public libraries have been taken out of the hands of librarians, teachers, and local communities and placed in the trust of proprietary software products" (Jaeger and Yan, 2009, "Filtering issues" section, para. 1). The software designer does not know curriculum and is not qualified to determine what might be reasonable and necessary for students to access online for a full 
educational experience, but by default they, rather than teachers or librarians, are making those decisions. Some software companies even have specific political agendas of which the purchaser may not be aware (Jaeger and Yan, 2009).

\section{Solutions}

How can school librarians and teachers address these issues? CIPA makes filtering in public schools mandatory. However, CIPA is specific and limited as to what must be filtered. Proponents of free access of information, such as the school librarian, can advocate for measures that meet the requirements of CIPA, increase online access, and still preserve and even improve the safety of students in an online environment.

One possible solution, if budget allows, is to use newer security technology that examines content rather than denying an entire site. New security technologies can filter out inappropriate content more effectively than their predecessors can, enabling the use of social media while still blocking infected or inappropriate sections (Ramaswami, 2010). Older technology would just block the entire site (Ramaswami, 2010). While this is a great first step, school districts may not have the budget to invest in these advanced security tools. However, there are other steps that can be taken to help students access Web. 2.0 sites and still provide protection from inappropriate content.

For example, schools can relax the filter by setting it to block only those sites that the school and stakeholders either identify as "inappropriate matter" or are not ready to support such as Facebook or Instagram (Jansen, 2010). Filters can also be set differently at different levels of education, with the most restrictive at the elementary level and the least restrictive at the high school and staff level (Jansen, 2010). Schools should also give immediate override authority to school librarians, teachers, and staff rather than making them seek permission from the district or a remote technology person. Providing the school librarian with the authority to override will help to shift the role of the school librarian to "information literacy specialist", and will offer "teachable moments" for the librarian to address the assessment of credibility and appropriateness (Willard, 2010).

Although a "looser" filter may allow in more inappropriate content, schools can protect their students in other ways. Physical monitoring by faculty and staff may be an option in some situations (Willard, 2010), and at the younger grades, teachers can preselect and prescreen sites and bookmark them for students, or preselect the databases and search engines for the students (Chapin, 1999). Most importantly, each school should educate its students. They can and should train their teachers and offer courses in Internet ethics, safety, security, and responsible use of social media tools. Schools must have an Acceptable Use 
Policy, make sure the students understand it, and enforce the policy by removing Internet privileges from those who don't abide by the policy (Meeder, 2005).

\section{Conclusion}

Even though filtering software is currently mandatory at public K-12 schools, the reach of CIPA is limited and does not necessarily require blocking Web 2.0 sites. Furthermore, filtering software has proven to be problematic and ineffective in truly protecting student from inappropriate content. Students should still be able to access the information they need to receive a $21^{\text {st }}$ century education while remaining largely protected from inappropriate content. This is not an issue that will go away - in fact, the issue will become even more pressing as the impact of technology in our schools and society continues to grow. It is up to school librarians, teachers, and administrators to carefully balance the benefits of filters and the need to protect children from inappropriate online content against the limitations of filtering and the need to provide our students with access and information so that they can be successful in navigating a digital world. Going forward, this will require increased communication between teachers, administrators, IT specialists, and the community regarding desired technology teaching tools, online access requirements for a $21^{\text {st }}$ century education, filtering requirements, community standards, and filtering limitations. It will also require an increased focus on alternative tools for protecting students, including education on online ethics, safety, and security. 


\section{References}

Adams, H.R. (2010). Intellectual freedom online: The new battleground for minors' First Amendment rights. Knowledge Quest 39(1), 10-15.

American Association of School Librarians (2012). Filtering in schools: AASL executive summary. Retrieved from http://www.ala.org/aasl/research/slc/2012/filtering.

American Association of School Librarians (2012). School libraries count!: Supplemental report on filtering (pp. 13-16). Chicago: AASL.

American Civil Liberties Union v. Gonzales, 478 F.Supp.2d 775 (E.D. Pa. 2007), aff'd sub nom. American Civil Liberties Union v. Mukasey, 534 F.3d 181 (3d Cir. 2008), cert. denied, 129 S. Ct. 1032 (Jan. 21, 2009).

American Library Association (2012). Filtering continues to be an issue for schools across the country. Chicago: ALA. Retrieved from http://www.ala.org/news/press-releases/2012/10/filtering-continues-beissue-schools-across-country.

Arafeh, S., Lenhart, A., Rankin Macgill, A., Smith, A. (2008). Writing, Technology and Teens. Pew Internet \& American Life Project. Retrieved from: http://www.pewinternet.org/ /media//Files/Reports/2008/PIP_Writing_Re port_FINAL3.pdf.pdf

Ashcroft v. Free Speech Coalition, 535 U.S. 234 (2002).

Bill \& Melinda Gates Foundation (2010). Primary sources: America's teachers on America's schools. U.S.A.: Scholastic Inc.

Byrd, V., Felker, J., \& Duncan, A. (2001). Bess won't go there: A research report on filtering software. Current Studies In Librarianship, 25(1/2), 719.

Chapin, B. (1999). Filtering the Internet for young people: The comfortable Pew is a thorny throne. Teacher Librarian (26)5, 18-22.

Child Online Protection Act, 47 U.S.C. $\$ 231$ (1998).

Child Pornography Prevention Act, 18 U.S.C. $§ 2251$ (1996). 
Children’s Internet Protection Act, 47 U.S.C. § 254 (2001).

Chmara, T. (2010). Minors' First Amendment rights: CIPA \& school libraries. Knowledge Quest, 39(1), 16-21.

Communications Decency Act, 47 U.S.C. § 223, 230 (1996).

Digest of Education Statistics (2012). Table 120: Number and Internet access of instructional computers and rooms in public schools, by selected school characteristics: Selected years, 1995-2008). Retrieved from U.S. Department of Education, Institute of Education Sciences, National Center for Education Statistics website:

http://nces.ed.gov/programs/digest/d10/tables/dt10_108.asp

Cortesi, S., Duggan, M., Gasser, U., Lenhart, A., and Madden, M. (2013). Teens and Technology 2013. Pew Research Center's Internet \& American Life Project. Retrieved from Pew Internet website at http://www.pewinternet.org/ /media//Files/Reports/2013/PIP_TeensandTe chnology2013.pdf

Federal Communications Commission (2013). Consumer guide: Children's Internet Protection Act (CIPA). Washington, D.C.: Government Printing Office. Retrieved from www.fcc.gov/consumer-governmental-affairsbureau.

Heins, M, Cho, C., \& Feldman, A. (2006). Internet filters: A public policy report. New York: Brennan Center for Justice.

International Society for Technology in Education (2012). ISTE standards for teachers. Retrieved from http://www.iste.org/docs/pdfs/nets-tstandards.pdf?sfvrsn=2

Jaeger, P. and Yan, Z. (2009). One law with two outcomes: comparing the implementation of CIPA in public libraries and schools. Information Technology and Libraries, 28(1), 6-14.

Jansen, B.A. (2010). Internet filtering 2.0: Checking intellectual freedom and participative practices at the schoolhouse door. Knowledge Quest, 39(1), 46-53. 
Lazarinis, F. (2010). Online risks obstructing safe Internet access for students. The Electronic Library, 28(1), 157-170.

Maness, J. M. (2006). Library 2.0 theory: Web 2.0 and its implications for libraries. Webology 3(2).

Meeder, R. (2005). Access denied: Internet filtering software in K-12 classrooms. Techtrends: Linking Research \& Practice To Improve Learning, 49(6), 56-58.

Menuey, B. (2009). CIPA: A brief history. Computers In The Schools, 26(1), 4047. doi: 10.1080/07380560802688265

National Cyber Security Alliance (2011). The 2011 State of Cyberethics, Cybersafety, and Cybersecurity Curriculum in the U.S. Survey - Fact Sheet. Retrieved from http://staysafeonline.org/teach-onlinesafety/resources/.

Purcell, K., Heaps, A., Buchanan, J. \& Freidrich, L. (2013). How Teachers Are Using Technology at Home and in Their Classrooms. Pew Research Center's Internet \& American Life Project. Retrieved from http://pewinternet.org/Reports/2013/Teachers-and-technology.

Ramaswami, R. (2010). Nothing to LOL about. T.H.E. Journal, 37(6), 24-26.

Reno v. ACLU, 520 U.S. 1113 (1997).

U.S. Department of Education (2010). Transforming American education: Learning powered by technology. National Educational Technology Plan 2010. Retrieved from www.ed.gov/technology/netp-2010.

U.S. Department of Education, National Center for Education Statistics. (2010). Teachers' Use of Educational Technology in U.S. Public Schools: 2009 (NCES 2010-040). Retrieved from http://nces.ed.gov/pubs2010/2010040.pdf

U.S. v. American Library Assn., Inc., 539 U.S. 194 (2003). 
Watters, A. (2012, May 7). When schools' Internet filters follow you home [Web log post]. Retrieved from http://hackeducation.com/2012/05/07/when-school-internet-filters-followyou-home-cipa/

Willard, N. (2010). Teach them to swim. Knowledge Quest, 39(1), 54-61. 